\title{
陸上競技場人エサーフェスの簡易評価システムの開発
}

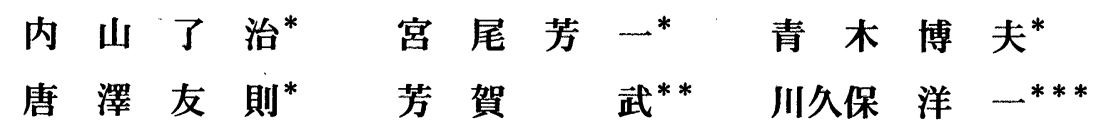

\section{Development of a Simple Evaluation System for Athletic Surfaces ${ }^{\dagger}$}

\author{
Ryoji UCHIYAMA * , Yoshikazu MIYAO * , Hiroo AOKI * , \\ Tomonori KARASAWA * , Takeshi HAGA ${ }^{* *}$ and Yoichi KAWAKUBO $* * *$
}

\begin{abstract}
The artificial surfaces of athletic stadiums comply with the standards of IAAF (International Association of Athletics Federations) and JAAF (Japan Association of Athletics Federations). The standards of IAAF consist of 10 properties, such as imperfections, sample thickness, force reduction and modified vertical deformation. It is demanded that the stadium where the international athletic meet is held fills these standards. However, these standards are adapted at the time of the construction of the stadium. The repair standards related to the change of passing years and use frequency are not defined. In order to prevent the occurrence of sports injuries, it is necessary to make clear the changes according to the passing years of the stadium. The purpose of this study was to develop a system that is able to evaluate mechanical characteristics of the surface, the practicality of this system, and the surface objectively. The results of this study are as follows:

(1)The form of pin and surface hardness exert an influence on the pressing of the pin.

(2)The surface damage of the athletic stadium was determined by this system. Measurement items are thickness, the pressing displacement quantity of pin, hardness, restitution coefficient and surface observation.

(3)This system is suitable for use as the pre-survey of the IAAF attestation organization, although it is a simple model.
\end{abstract}

Key words : Simple Evaluation System, Mechanical Characteristic, Track Surface, Spike Pin

\footnotetext{
原稿受付 2005 年 10 月 11 日

2005 年 7 月 日本スポーツ産業学会第 14 回大会（神戸市）にて一部発表

${ }^{*}$ 長野工業高等専門学校 テ381-8550 長野県長野市大字徳間 716

**ハーガード サイエンス アカデミー テ 381-0057 長野県長野市浅川西条 895

***信州大学 テ 381-8553 長野県長野市若里 4-17-1

${ }^{*}$ Nagano National College of Technology, 716, Tokuma, Nagano, Nagano, Japan (381-8550)

**Hargard Science Academy, 895, Asakawa, Nishijo, Nagano, Nagano, Japan (381-0057)

*** Shinshu University, 4-17-1, Wakasato, Nagano, Nagano, Japan (381-8553)
} 


\section{1.はじめに}

陸上競技場全天候走路の人エサーフェス（以 下，サーフェス）は，国際陸上競技連盟（以下, IAAF）および(財) 日本陸上競技場連盟（以下, JAAF）により基準が設けられている.IAAF の マニュアル(認証制度 $)^{12)}$ と JAAF のルールブッ
ク $(\text { 検定制度 })^{3) 45)}$ の概要を表 1 に示す.

IAAF の認証制度は1999 年に公表され，「用 器具」,「全天候表面舗装材」，そして「トラッ クの認証」からなり，オリンピックや国際的な 競技会が開催される競技場はこれらの基準を満 たし，IAAF 認証機関による現地検査での合格 が要求されている. 鈴木・中川(6)7)8)によるこの

表 1 IAAF 認証制度と JAAF 検定制度の比較

\begin{tabular}{|c|c|c|c|}
\hline & 項 目 & IAAF (国際陸連) & JAAF（日本陸連） \\
\hline $\begin{array}{l}\text { 制 } \\
\text { 度 } \\
\text { 概 } \\
\text { 要 }\end{array}$ & $\begin{array}{l}\text { 制度公表 } \\
\text { 認証の種類 } \\
\text { 認証·公認期間 } \\
\text { 補助競技場 } \\
\text { 各種施設 } \\
\text { 収容人員 } \\
\text { 雨天走路 } \\
\text { 用器具 } \\
\text { 用器具庫 } \\
\text { 検査員 } \\
\end{array}$ & $\begin{array}{l}1999 \text { 年 } \\
2 \text { 種類 (class1, 2) } \\
4 \text { 年間 } \\
\text { 別規定あり } \\
\text { 別規定あり } \\
\text { 別規定あり } \\
\text { 別規定あり } \\
\text { 明記無し } \\
\text { 明記無し } \\
\text { IAAF公式検查員 }\end{array}$ & $\begin{array}{l}1929 \text { 年 } \\
5 \text { 種類(第1 } 5 \text { 種) } \\
5 \text { 年間 (第5 } 5 \text { 種は3年間) } \\
\text { 第 } 1 \text { 種には全天候第3種が必要 } \\
\text { 仕様で種類と数の規定あり } \\
\text { 種別に規定あり } \\
\text { 第1種に規定あり } \\
\text { 種別に種類と数の規定あり } \\
\text { 規定あり } \\
\text { JAAF検定員 }\end{array}$ \\
\hline 認 & $\begin{array}{c}\text { 全天候舗装材 } \\
\text { (サンプルの検査) }\end{array}$ & $\begin{array}{l}\text { ・10項目 } \\
\text { 表面欠陥(瑕泚) } \\
\text { 表面平坦性 } \\
\text { サンプル厚さ } \\
\text { 衝擊吸収性 } \\
\text { 垂直方向変位量 } \\
\text { 摩擦性能 } \\
\text { 引張強度 } \\
\text { 破断時伸び率 } \\
\text { 色調 }\end{array}$ & $\begin{array}{l}\text { ・第 } 1,2 \text { 種はIAAFに準ずる } \\
\text { ・硬度 } \\
\text { ・摩耗, 亀裂しにくいもの } \\
\text { ・下地との接着性 }\end{array}$ \\
\hline 検 & $\begin{array}{l}\text { トラック 距 離 } \\
\text { フィールド } \\
\text { (現地検查) }\end{array}$ & $\begin{array}{l}\text { ・上記10項目 } \\
\text { (引張試験は, ト } \\
\text { ラックからサンプル } \\
\text { を抜き取る) } \\
\\
\text { 明記無し }\end{array}$ & $\begin{array}{l}\text { ・新設時 : サンプル検查 } \\
\text { 厚さ } \\
\text { 硬度 } \\
\text { ・検定時 : 目視検査 } \\
\text { 表面欠陥(瑕漉，膨れ，剥離) } \\
\text { 色調 } \\
\text { ・許容誤差 第 } 1,2 \text { 種は } 1 / 10000 \\
\text { 第3〜 種は各 } 4 \mathrm{~cm} \\
\text { 巻尺温度補正, 測点詳細規定あり }\end{array}$ \\
\hline 項 & 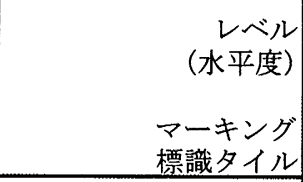 & \begin{tabular}{|l} 
明記無し \\
明記無し \\
明記無し
\end{tabular} & $\begin{array}{l}\text { ・トラック : 各レーン } 5 \text { 〜0m毎計測 } \\
\text { ・フィールド : } 10 〜 20 \mathrm{~m} \text { 格子状に計測 } \\
\text { 規定あり } \\
\text { 規定あり，角度検查 }\end{array}$ \\
\hline 目 & 施設, 用器具 & \begin{tabular}{|l} 
・施設 \\
明記無し \\
(競技規則で対応) \\
\\
\\
\\
・用器具 \\
明記無し \\
(競技規則で対応)
\end{tabular} & $\begin{array}{l}\text { ・施設 } \\
\text { 各施設詳細に規定 } \\
\text { (例) 走幅跳ピット } \\
\text { 砂場サイズ, 踏切板と砂場の位置確認, } \\
\text { 踏切板およひ砂場のレベル, 踏切板埋設・ } \\
\text { 取り替え状況, 助走路の距離とレベル } \\
\text { ・用器具 } \\
\text { 種類と数規定あり…確認 } \\
\text { 損佰状況，規格，重さ等の確認 } \\
\end{array}$ \\
\hline
\end{tabular}


制度の現状および今後の展望に関する報告のと おり，国内においては IAAF とJAAF の 2 本立 ての制度が存在することになるため，その整合 性と今後の IAAF の動向に注目する必要がある と思われる. サーフェス性能規格については, 表面欠陥 (瑕疵), 垂直方向変位量, 衝撃吸収 性等の物性および機械的特性に関する 10 項目 について細かく規定されている。この規格は, 国内の第 $1 \cdot 2$ 種公認陸上競技場においても準 ずることが JAAFにより規定されているため, 舗装材を取り扱う業者が IAAF 認証機関でサン プルの検査を受けこれらの基準を満たした舗装 材が, 新設される国内の第 $1 \cdot 2$ 種競技場に施 エされている.

JAAF の基準に関しては，公認陸上競技場お よび長距離競走路ならびに競歩路規定 ${ }^{3)}$, 全天 候舗装公認陸上競技場の細則 ${ }^{4}$ および第 1 種・

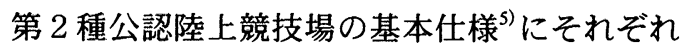
公認競技場の種類, 構造物, 各種施設, 用器具, レーンマーキングおよびカラーリングなどにつ いて詳細に規定されている.

また, JAAF では 5 年（第 5 種競技場に限り 3 年）毎の検定制度が設けられ改修および検定 が実施されている。しかし，JAAFの検定項目 はトラックの「距離」,「各施設」,「レベル（水 平度)」に主眼が置かれ, IAAF の認証制度に あるようなサーフェスの機械的物質特性に関 する材料試験を伴う規定や，競技場サーフェス を部分的に採取して行う試験項目はない. 同時 にこれらのIAAFとJAAF の規定は，競技場が 新設されるときの初期基準であり, 経年的変化 や使用頻度による改修基準は明確にされていな い.

従って, サーフェスの補修・改修および検定 時には, 目視検査が中心となり, サーフェスの 機械的特性までは考慮されていない状況にあ る. 検定時の改修工事内容に関しては競技場所 有者の財政的な理由もあり, サーフェスの部分 的な補修によるレーンの格差が生じ, 競技者に とって平等性原則を損なうおそれのある競技場 が存在するのも事実である. 特に, 使用頻度が
高く劣化摩耗により薄くなったサーフェスは, 競技者の障害発生につながる危険性もあり問題 が大きい.これを解決するためには現場で手軽 にサーフェスを評価し, 競技場維持管理者に改 修を働きかけることが必要であるが, その手段 や方法がなく客観的な資料を得ることができな いのが現状と言える.

サーフェスの层疵や損傷は, 使用状況や気象 等により程度差が大きい.これらの損傷につい て，内山ら" は発生状況をもとに分類している が，表面的損傷をもとにした分類であり，さら に詳細な調查と評価が必要と言える. サーフェ スの機能特性に関する研究は実験的 ${ }^{(0)-16)}$ ある いはシューズの機能性を高める ${ }^{17)-20)}$ 中で行わ れてきている. また, 古川 ${ }^{211}$ はスポーツサーフェ スの各種衝撃緩衝能評価試験法を比較検討して いるが, 人の体内での調節の要因を除去する困 難さや学際的な研究の必要性を指摘している.

一方, 膝関節障害, 前傾骨筋疲労症候群や疲 労骨折などスポーツ障害 ${ }^{222}$ 23)に悩む競技者は多 い. 菊川ら 2425) ${ }^{24}$ はポーツで生じやすいと考え られる特殊なせん断力が関節軟骨障害にどのよ うに影響するかを検討し，スポーツによるせん 断損傷発生メカニズムについて，材料力学的観 点から, 繰り返しせん断力は関節端の損傷発生 に破壊的かつ加速的に㗢くことを報告してい る. 硬いサーフェスや損傷したサーフェスでは スポーツ障害の可能性は高まるため, 障害発生 を抑える観点からもサーフェスの改修基準と損 傷を簡単に調查できるシステムの必要性が高い と言える.

そこで，本研究では，陸上競技場サーフェス を現場で評価するシステムを構築することお よびその実用性を評価し，陸上競技場改修基 準作成に必要な基礎的知見を得ることを目的と した. サーフェス評価項目は IAAF, JAAFおよ びJSAF（(財) 日本体育施設協会屋外施設部会） の基準を参考に，サーフェスに関する複数の機 械的特性（厚さ, 硬度, スパイクピンのサーフェ ス圧入変位, 反発係数, 表面観察) とした。 
表 2 IAAF サンプル舗装材評価項目と本研究の評価項目の関連

\begin{tabular}{|c|c|c|}
\hline IAAF評価項目 & 本研究評価項目 & 備 \\
\hline 表面欠陥(瑕疵) & CCDカメラ観察 & 目視でも可能だが，CCDカメラによりクラックを詳細に観察する \\
\hline 表面平坦性 & 採用せず & JAAF検定ではレベル測定を行らため表面の不陸は精查されている \\
\hline サンプル厚さ & 厚さ測定 & 厚さ \\
\hline 衝撃吸収性 & 反発係数, 硬度で代替 & 大がかりな落鍾機が必要なため，手軽に実施可能な項目とした \\
\hline 垂直方向変位量 & ピン圧入変位で代替 & 上記同様の理由で, ピンの圧入変位(垂直変位量)とした \\
\hline 摩擦性能 & 採用せず & 装置が必要なため \\
\hline 引張強度 & 採用せず & 引張試験が必要で現場でできない \\
\hline 破断時伸び率 & 採用せず & 引張試験が必要で現場でできない \\
\hline 色調 & 採用せず & 目視で可能 \\
\hline
\end{tabular}

2. サーフェス簡易評価システム

\section{1 サーフェスの評価項目}

サーフェスの評価項目は IAAF 基準をもとに 表 2 に示すとおり, サーフェスの変位（ピンの 圧入変位), 硬度, 厚さ, 表面観察および反発 倸数とした．項目の選定にあたり競技場サー フェスを採取した破壊試験は行わず，非破壊検 査で対応できる項目であることを基本方針とし た. そして、サーフェスの状態を客観化できる こと，陸上競技場現場で容易に測定し結果がわ かること, 複数箇所を少人数で測定できること を条件に選定した。

\section{2 システムの具備すべき条件}

（1）システムが軽量で，陸上競技場現場への持 ち運び，設定および試験が容易に行える.

(2) 複数の特性が評価できる.

( 3 ) 荷重などのパラメー夕を変化させられる.

(4) 測定データをパソコンに取り込むことが可 能で, 現場で結果がわかる.

\section{3 システムの構成}

図 1 に示す本システムの構成は, サーフェス の変位・硬度・厚さ測定部, 表面観察部, そし て反発係数測定部からなる.

\section{(1) 変位 $\cdot$ 硬度 $\cdot$ 厚さ測定部}

スパイクピンを図 1-Aに取り付ける. 負荷 を加えるとガイド（図 1-C）に沿って可動部 (図 1 - B )がスムーズに下降しピンがサーフェ スに圧入される。これと連動して変位計（図１ 一D）が作動し, 変位に比例した電圧值がパー ソナルコンピュータに取り込まれる。 また, ピ ンの代わりにデューロメータ硬度計をセットす ればサーフェス表面の硬度が測定できる.

サーフェス厚さの定義に関しては図 2 に示 す。本研究では次式（1）とした。

サーフェスの厚さ

$\mathrm{L}=\mathrm{L}_{1}-\mathrm{L}_{2} / 2$

$\mathrm{L}_{1}$ ：エンボス最高（凸）点からアスファルト・ コンクリート層までの長さ

$\mathrm{L}_{2}$ : エンボス最下（凹）点から最高（凸）点 までの長さ

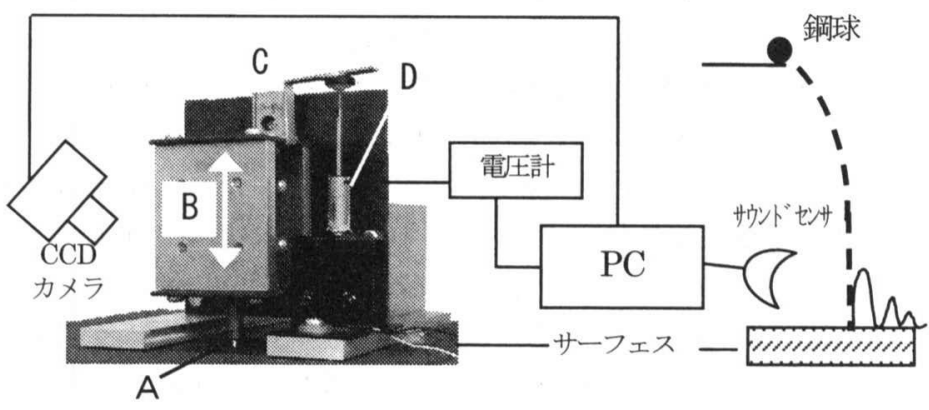

図 1 システムの構成 
表面層

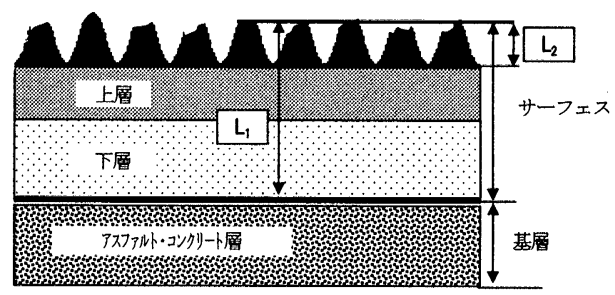

図 2 サーフェスとサーフェス厚さの定義
厚さ測定は, IAAFによれば目盛りのついた探 査針を使用し，この值が $10 \mathrm{~mm}$ 以下の場合は 直径 $10 \mathrm{~mm} \sim 25 \mathrm{~mm}$ で舗装のコアを抜き取り 再調査することになっている，本研究では，図 1 - A 部分に専用の探査針を装着し，連動する 変位計の値を取り込む.

\section{（2）表面観察部}

パーソナルコンピュータに接続されている CCD カメラにより，サーフェス表面を微視的 に観察しその画像を取り込む. その画像から接 触面積等を算出することもできる.

\section{（3）反発係数測定部}

体䏍施設の各種表層材を評価する反発試験26) は, GB 反発試験（ゴルフボール）, SB 反発試 験 (スチールボール), TB 反発試験（テニスボー ル）が汎用的に行われている. これらは各ボー ルの反発した高さを測定し係数を求めるもので あり，目視による測定は誤差を含み，VTR 等に 撮影し算出する場合は即時性がない. 須藤ら ${ }^{27)}$ はこれらの誤差を減少させるために高速度力メ ラを用いて衝突挙動解析を行っている. また, 上原ら ${ }^{28)}$ は $\mathrm{AE}$ (Acoustic Emission) センサを利 用し, 衝突時の音を検出する手法をもちいて, 独自の計測システムを開発し, 実験值と理論值 を比較検討し有効性を検証している. 本研究で は，これらを参考に，スチールボールが衝突す るときの衝撃音から即時に反発係数を求めるも のである.

反発係数は, 図 3 に示すように, 高さ $h_{1}$ か ら球体が自由落下し $\mathrm{t}_{1}$ 秒後に速度 $\mathrm{v}_{1}$ で床面に 衝突して跳ね返り, 速度 $-v_{2}$ で高さ $h_{2}$ まで上昇 し再び $\mathrm{t}_{2}$ 秒後に衝突する.この跳ね返りを繰
(高さ

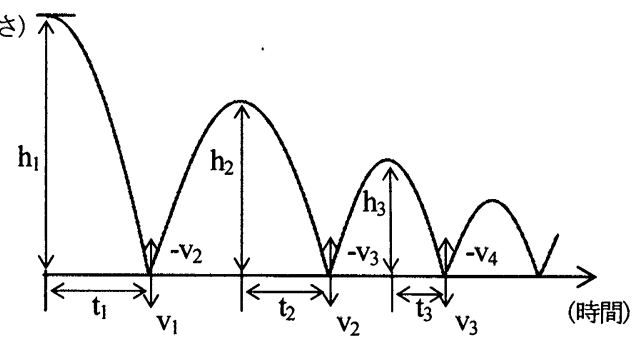

図 3 反発係数算出モテル

り返す場合, 反発係数 $\mathrm{e}$ は次式 (2)で定義され る.

$\mathrm{e}=\mathrm{v}_{2} / \mathrm{v}_{1}=\mathrm{v}_{3} / \mathrm{v}_{2}=\cdots \cdots$

$\mathrm{t}_{1}$ : 自由落下開始から床面に衝突するまでの 時間

$\mathrm{t}_{2}$ : 最初の衝突から跳ね返り, 再度床に衝突 するまでの時間

$\mathrm{t}_{3}: 2$ 回目の衝突から跳ね返り, 再び床に衝 突するまでの時間

また, 重力加速度を $\mathrm{g}$ とすると

$\mathrm{v}_{1}=\mathrm{gt}_{1}$ および $\mathrm{v}_{2}=\mathrm{gt}_{2}$ なので,

$\mathrm{e}_{1}=\mathrm{v}_{2} / \mathrm{v}_{1}=\mathrm{gt}_{2} / \mathrm{gt}_{1}=\mathrm{t}_{2} / \mathrm{t}_{1}, \mathrm{e}_{2}=\mathrm{t}_{3} / \mathrm{t}_{2}$,

$\mathrm{e}_{\mathrm{i}}=\mathrm{t}_{\mathrm{i}+\mathrm{l}} / \mathrm{t}_{\mathrm{i}}$ となり, 衝突間隔の時間を測定して も反発係数は求められる.

本研究では, $2 \mathrm{t}_{2}, 2 \mathrm{t}_{3}$ を計測し, 次式(3) と定 義する.

$$
\mathrm{e}=2 \mathrm{t}_{3} / 2 \mathrm{t}_{2}
$$

\section{3. システムの作動確認とサーフェスの評価}

\section{1 目的}

本システムの機能を確認するとともに, 種類 の異なるサーフェスとスパイクピンの影響につ いて考察を試みた。 具体的な目的は次の 3 項目 である.

(1) 3 種類のサーフェスとスパイクピン (以下, ピン）の圧入変位を明確にする.

( 2 ) ピンの違いによる圧入変位を明確にする.

( 3 ) ピンの圧入痕の観察.

\section{2 方法}

供試したサーフェスの特徵を表 3 に示す。試 料は，国内外の主要な競技場で使用されている 
表 3 供試サーフェスの特徴

\begin{tabular}{|c|c|c|c|}
\hline $7^{2}$ & 試料 a & 試料 b & 試料 c \\
\hline 断面写真 & & & \\
\hline 硬度 (A/S) & 56 & 58 & 54 \\
\hline 上層 $3 \mathrm{~mm}$ & \multicolumn{3}{|c|}{ ウレタン 共通 } \\
\hline 上層のみ硬度 $(\mathrm{A} / \mathrm{S})$ & \multicolumn{3}{|c|}{53} \\
\hline 下層 $9 \mathrm{~mm}$ & 特殊骨材入りウレタン弾性層 & ゴムチップ弾性層 & ゴムチップ弾性層 (工場製品) \\
\hline 下層のみ硬度 (E/S) & 67 & 78 & 57 \\
\hline
\end{tabular}

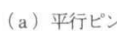

(b) 2 段ピン

(c) 3 段ピン

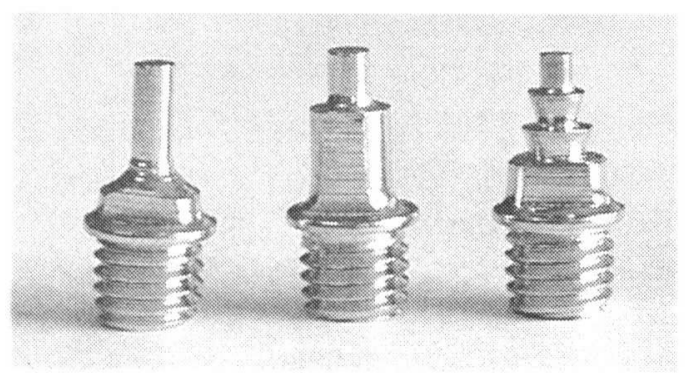

図4 供試スパイクピン

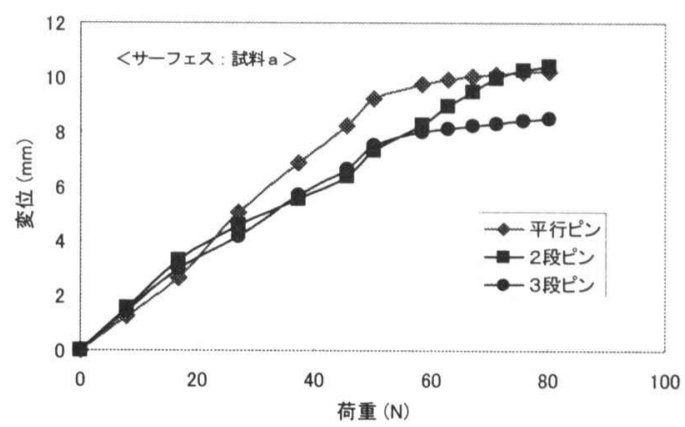

図 5 ピンの形状がおよぼす圧入変位

フルウレタンタイプ (試料 a ), 下層に硬めの 現場施工ゴムチップを使用したタイプ（試料 b ），そして，下層が軟らかい工場製品の棒状 ゴムチップタイプ (試料 c ) の 3 種類とした. 表面層は実験用に接触開始点の形状の影響を除 くためフラット仕上げとした。 上層は 3 試料と もウレタン製で, 上層の厚さは同一とし，全体 で $13 \mathrm{~mm}$ とした.

図 4 にピンを示す。ピンは陸上競技において 汎用的に用いられ形状の違う 3 種類 (平行ピン, 2 段ピン，3段ピン) とし，長さはすべて $8 \mathrm{~mm}$ とした.

サーフェス表面温度および室内温度は $23( \pm$ 2） ${ }^{\circ} \mathrm{C}$ で実験を行った.

\section{3 結果}

\section{(1) 変位 $\cdot$ 硬度測定部}

3 種類のピンにおける荷重とサーフェスの変 位を図 5 に示す．変位は, ピンのサーフェス圧 入深さと, サーフェスの弾性変位の和である. 荷重と変位の関係は約 $55 \mathrm{~N}$ までは比例関係を 示し, その後は飽和傾向にあり, ピンの台座お よびピンの取り付け部分全体でサーフェスを変 形させていることが分かった。 また，圧入の 状況は, 平行ピンと 2 段ピンは, ピンの台座ま で約 $8 \mathrm{~mm}$ はスムーズに圧入したが， 3 段ピン は 2 段目（約 $6 \mathrm{~mm} ）$ までしか圧入しなかった。 これらからサーフェスへのピンの圧入はピン形 状（段差）の影響を受けていることが推測され る. 


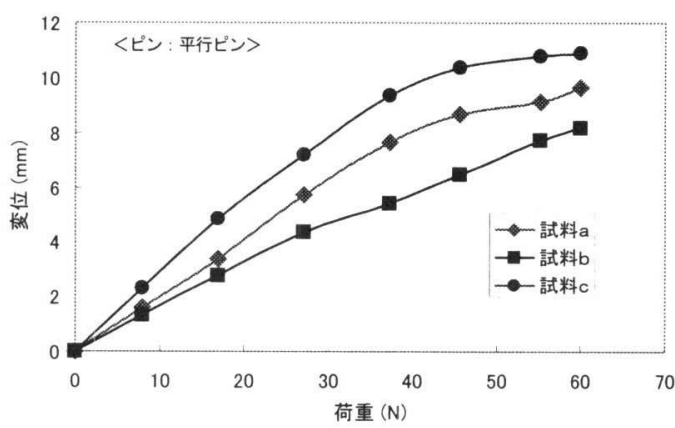

図 6 サーフェスの違いがおよぼす圧入変位

硬度は, JIS K6235 の試験方法により A およ びEデューロメータにより測定し，結果は表 3 に示した。試料全体の硬度（A/S）は試料 b が最も硬く cが最も軟らかい值を示した．下層 の夕の硬度（E/S）も同等で b, a, c の順に高 い值であった。これらのサーフェスの上層の材 質は同一のため, サーフェスの硬度は下層の硬 さに影響すると言える。

図 6 にサーフェスの違いがおよぼす圧入変位 を示す。試験は長さ $8 \mathrm{~mm}$ の平行ピンを使用し, ピンが完全にサーフェスに圧入するまで荷重し た. 変位は 3 種類の試料とも荷重に比例して増 大し, 硬度が大きい試料 $\mathrm{b}$ の圧入変位が最も小 さく, 最も硬度の小さい試料 $\mathrm{a}$ は, $48 \mathrm{~N}$ でピン 全体が圧入しそれ以降はピンの台座がサーフェ スに密着した。これらから，硬度が大きいサー フェスほどピン圧入の変位が小さい傾向が認め られた。

\section{（2）圧入痕の観察}

サーフェス表面の圧入痕を, CCD カメラ（レ ンズ倍率 50 倍）を用いて観察した。図 7 (a) が平行ピン，（b )が 2 段ピンによる圧入痕であ る. 平行ピンの方が, 中心部の破壊が大きく, クラックが内部まで観察された. 2 段ピンの先 端の太さは平行ピンと同様であるが, クラック の発生状況については明らかな差が観察され, ピンの形状により圧入痕が異なることが分かつ た.

\section{（3）反発係数の測定}

反発係数の測定には, 直径 $34.92 \mathrm{~mm}$, 重さ

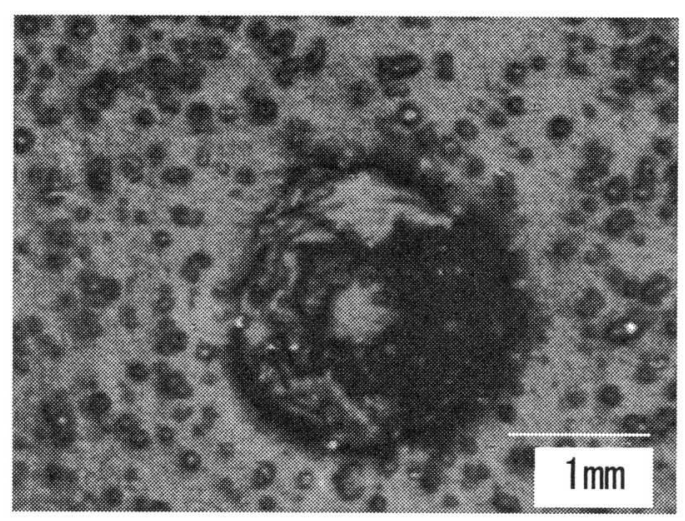

(a) 平行ピン

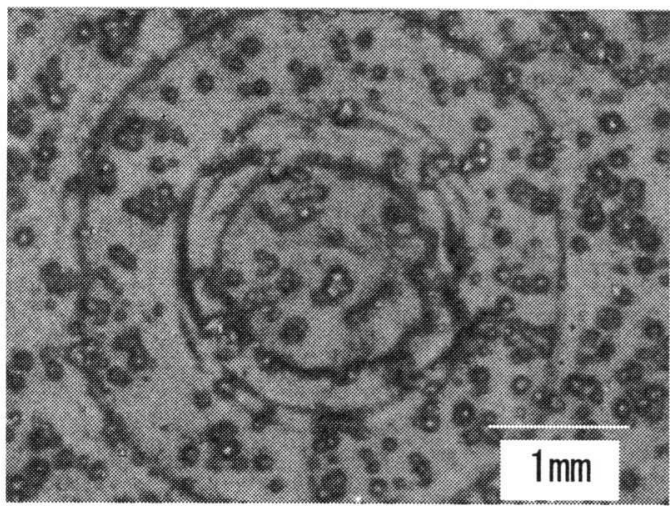

(b) 2 段ピン

図 $7 \mathrm{CCD}$ カメラによるピンの圧入痕の観察 〈サーフェス：試料 a >

表 4 反発係数

\begin{tabular}{|c|c|c|c|}
\hline 反発係数 & $\mathrm{a}$ & b & $\mathrm{C}$ \\
\hline $\begin{array}{c}e_{1} \\
\left(t_{3} / t_{2}\right)\end{array}$ & 0.551 & 0.528 & 0.596 \\
\hline
\end{tabular}

$173.55 \mathrm{~g}$ の鋼球を使用し， $0.1 \mathrm{~m}$ の高さから自由 落下させ, 衝突音を収集し反発係数を算出した. 測定結果は表 4 に示したとおりである。これ らから本システムは衝突音の収集で反発係数を 算出できることが確認できた. 反発係数には試 料による差はほとんど認められなかった。それ は, 今回の試料は上層が同一材料ですべて未使 用のものであること, 落下物の重さおよび高さ の設定条件によるものと思われる. 
以上の結果から, 本システムはサーフェスの 変位, 硬度, 厚さが測定でき, 表面観察および 反発係数が求められること, サーフェスやピン の違いを検出できることが確認された.

\section{4. 陸上競技場のサーフェス損傷状況の評価}

\section{1 目的}

本システムを陸上競技場に持ち込み, 損傷程 度が異なるサーフェスを評価する。

\section{2 方法}

\section{(1) 測定地点}

測定地点を図 8 に示す。サーフェスの損傷状 況を目視により確認し, 損傷が大きい箇所とし てフィニッシュ 1 レーン, 損傷が少ない箇所と してフィニッシュ 9レーンを選定した. 測定場 所は,それぞれのレーン中央部分の $0.1 \mathrm{~m} \times 0.1 \mathrm{~m}$
の範囲と規定した.

\section{(2) 測定項目}

・サーフェスの厚さ, エンボスの高さ

厚さは, IAAFの方法に従い, エンボス凸部 と凹部の厚さを別々に測定しその平均値とし た. エンボスの高さは, 凸部と凹部の差の平均 とした.

- 硬度

・ピンの圧入変位

. 反発係数

落下物の走路への影響を考慮し, 直径 $34.92 \mathrm{~mm}$, 重さ $173.55 \mathrm{~g}$ の鋼球を使用し, $2 \mathrm{~m}$ の高さから自由落下させた.

・CCD カメラ (50 倍) による表面観察

\section{3 結果と考察}

測定項目と結果を表 5 に示した。サーフェ
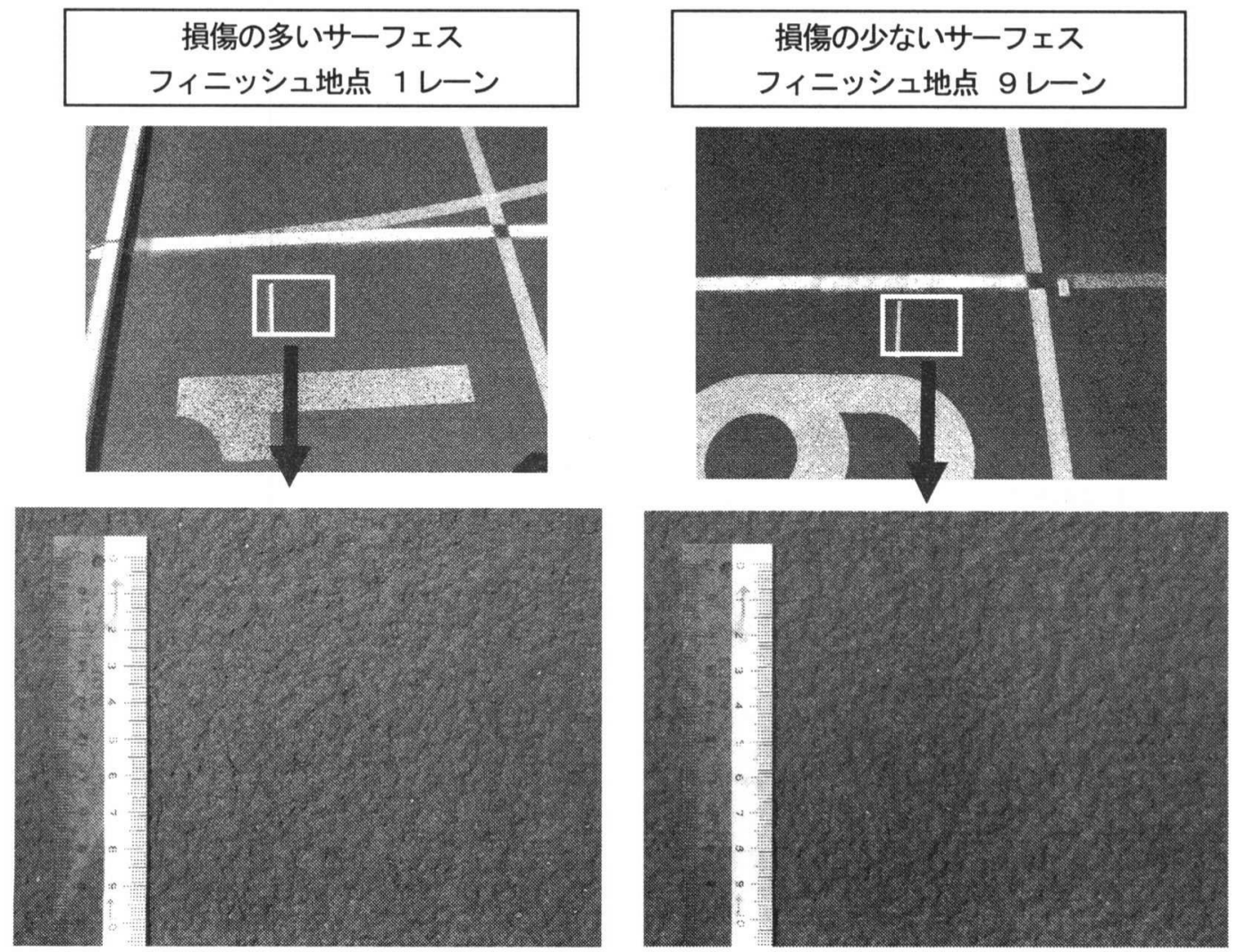

図 8 測定地点 
表 5 陸上競技場における測定結果

\begin{tabular}{cccccc}
\hline レーン & 目視 & $\begin{array}{c}\text { サーフェスの } \\
\text { 平均厚さ }(\mathrm{mm})\end{array}$ & $\begin{array}{c}\text { エンボスの } \\
\text { 高さ }(\mathrm{mm})\end{array}$ & $\begin{array}{c}\text { 硬度 } \\
(\mathrm{A} / \mathrm{S})\end{array}$ & 反発係数 \\
\hline 1 & 損傷大 & 10.34 & 0.17 & 48 & 0.606 \\
9 & 損傷小 & 11.86 & 1.34 & 58 & 0.613 \\
\hline
\end{tabular}

スの厚さは, 1 レーンは $10.34 \mathrm{~mm}, 9$ レーンは $11.86 \mathrm{~mm}$, 両レーンの差は, $1.52 \mathrm{~mm}$ で, 1 レー ンは表面層のエンボスがほとんど確認できない ほど摩耗が進行していた. 1レーンの損傷が大 きいことはどの陸上競技場も同様であり，厚さ の差違はこのことを裹付けていると言える. ま た, 初期厚さは規則では $13 \mathrm{~mm}$ であるが, 1 レー ン内側緑石近くの摩耗していない部分の厚みは $16 \mathrm{~mm}$ あり, 1 レーンは 10 年間の使用で $6 \mathrm{~mm}$ 厚さが減少している．毎年 $0.6 \mathrm{~mm}$ 摩耗してい る計算であり, $10 \mathrm{~mm}$ の現在の厚さは, 2 年後 にはピンの長さである $9 \mathrm{~mm}$ を切ることになる. 摩耗速度と残存膜厚を考えた管理方法が必要で ある。

硬度に関しては，1レーンが $\mathrm{A} 48 / \mathrm{S} ， 9$ レー ンが $\mathrm{A} 58 / \mathrm{S}$ を示し，1レーンは柔らかな状態で あることを示した.

図 9 はそれぞれのレーンにおける荷重とサー フェスへのピンの圧入変位を示したものであ る. 1 レーンと 9 レーンでは荷重 $30 \mathrm{~N}$ で，おお よそ $2 \mathrm{~mm}$ の変位差が生じ, 荷重 $45 \mathrm{~N}$ 付近でピ ン全体がサーフェスに圧入し，その後はピンの 台座を含めた部分でサーフェスと接触してい た. 損傷が大きい 1 レーンほど，柔らかく，変 位も大きな值を示した. しかし，厚さはピン の压入変位とほほ同等の $10 \mathrm{~mm}$ しかないため, サーフェスの厚さと競技者の安全性を考慮する 必要がある。疾走速度が $10 \mathrm{~m} / \mathrm{s}$ を超えるスプリ ントでは競技者が接地する際に，地面に加わる 力は垂直方向で $2000 \mathrm{~N}$ 程度 ${ }^{29)}{ }^{30)}$, 体重の 5.5 倍 31)，あるいは瞬間的な衝撃は $\left.4000 \mathrm{~N}^{32}\right)^{33)}$ を超え ることが報告されている. 従って, 1レーンの 厚さは IAAF 最低基準の $10 \mathrm{~mm}$ に近い値である ため, ピンはサーフェス路盤のアスファルト首

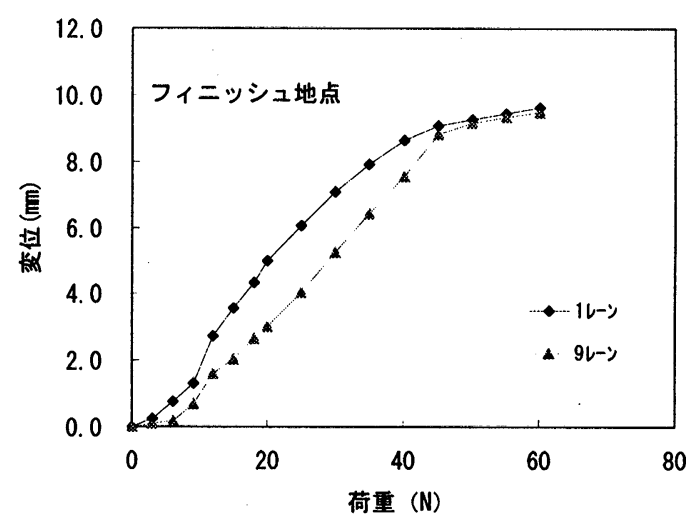

図 9 フィニッシュ地点における荷重とピンの圧 入変位

近くまで圧入し，衝撃吸収性も悪化し，危険な 状況であると推察される.

鋼球による反発係数については, 硬いサー フェスほど反発係数が高く，9レーンの方が良 く反発する状態であった. 小林ら ${ }^{34)}$ は反発係数 について，測定しやすい利点を生かし他の測定 法と併用して考察する場合には有効な指標であ ることを指摘している. 本研究でも複数の測定 項目と組み合わせることで, サーフェスの状態 を簡便に評価できる指標であることが考察でき た.

図 10 は, サーフェス表面の状態を, CCD カ メラ（レンズ倍率 50 倍）により観察したもの である. この写真からも, 1 レーンでは, クラッ クが大きく深く，損傷が激しいことが明確に なった.

これらのことから, 1 レーンと9レーンでは 客観的な差が認められ，1レーンは反発係数が 低く，柔らかいため，ピンも圧入しゃすい。 し かし，限界近くまで摩耗しているためピンがア スファルト路盤近くまで圧入し，競技者に危 
1レーン(損傷の多い地点)

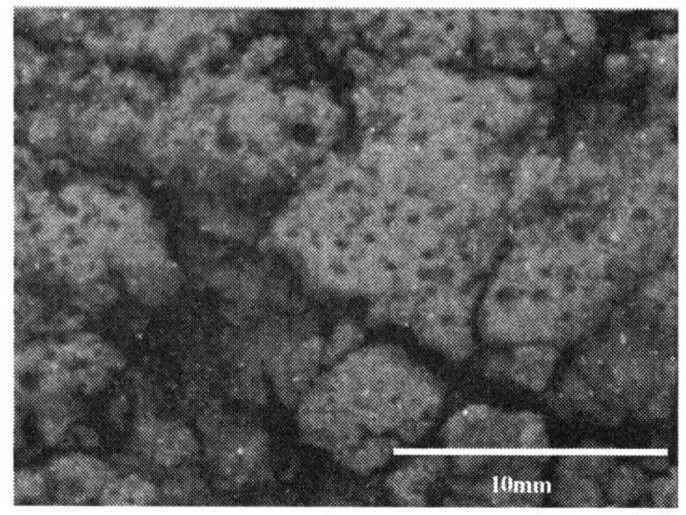

9 レーン(損傷の少ない地点)

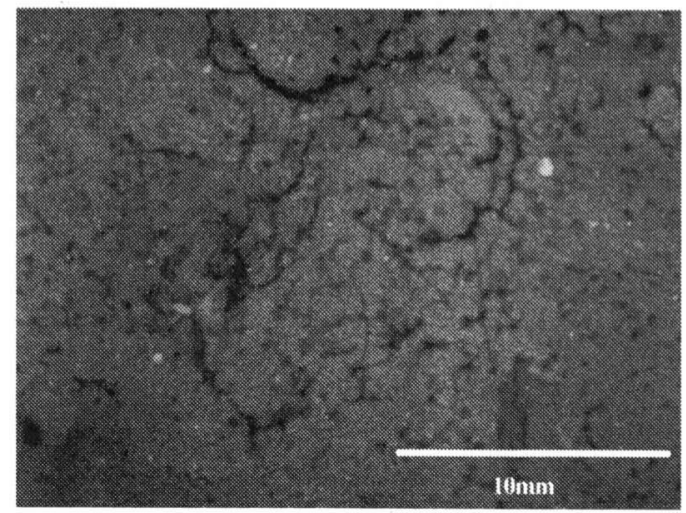

図 10 CCD カメラによるサーフェス観察

険な状況であることが判明した，厚さと硬度， 圧入変位量および反発係数の関係については, サーフェスが摩耗し薄くなれば, 柔らかくなる. そして, ピンは圧入しやすくなるとともに, 反 発力は低下するという傾向を明確にできた.

\section{5.まと め}

本研究では, 従来目視が中心であった既存の 陸上競技場におけるサーフェスの評価方法に関 して, サーフェスの機械的特性を手軽に簡易評 価できるシステムを開発した。このシステムの 実用性評価を試み，次の基礎的な知見を得た。

(1) ピン形状の違い, および, サーフェス硬度 の違いが, ピンの圧入変位に影響することが 分かった.

（2）本システムを活用し，陸上競技場におけ るサーフェス損傷の程度を, 厚さ, 硬度, ピ ンの圧入変位, 反発係数, および $\mathrm{CCD}$ カメ ラによる表面観察により評価することができ た.

（３）本システムは簡易型であるが IAAF 認証機 関等による調査の前段評価として，機能する ことが分かった。

今後は, 本システムの複合的な特徵を生かし, 垂直変位量, 反発係数, 表面クラック状況など のデータを総合的に検討し, これらの項目の規 格值の設定と陸上競技場改修の客観的な基準を 作成することが課題と言える.

\section{参 考 文 献}

1) IAAF : PERFORMANCE SPECIFICATION FOR SYNTHEYIC SURFACED ATHLETICS TRACKS , 1990.

2) IAAF : TRACK AND FIELD FACILITIES MANUAL (2003 edition), pp.93-116, MONACO, 2003.

3)（財）日本陸上競技連盟; 「公認陸上競技場お よび長距離競走路ならびに競歩路規定」, 陸 上競技ルールブック 2005 年版, あい出版, pp.179-193.

4 ）(財）日本陸上競技連盟; 「全天候舗装公認陸上 競技場の細則」，陸上競技ルールブック 2005 年版, あい出版, pp.194-203.

5 ）（財）日本陸上競技連盟；「第 1 種・第 2 種公認 陸上競技場の基本仕様」，陸上競技ルールブッ ク 2005 年版, あい出版, pp.164-178.

6 ）鈴木 存·中川喜矩 ; 国際陸連の認証制度に迫る (第一報), 月刊体育施設, No.428,pp.16-23.2004.

7 ) 鈴木 存·中川喜矩; 国際陸連の認証制度に迫る (第二報), 月刊体育施設, No.429,pp.28-31.2004.

8 ）鈴木 存·中川喜矩；国際陸連の認証制度に迫る (第三報), 月刊体育施設, No.430,pp.33-37.2005.

9 ）内山了治 他；陸上競技場人工サーフェスの損 傷分類と摩耗試験装置の開発，スポーツ産業 学研究, Vol.15,No.2,pp.37-45.2005.

10) RALPH MANN, PAUL SPRAGUE : A Kinetic Analysis of the Ground Leg During Sprint Running. RESERCH QUARTERLY FOR EXERCISE AND SPORT, Vol.51, No.2, pp.334-348, 1980. 
11) Miller.J.E, Baround.G., Nigg.B.M. : Elastic behavior of sport surface materials. Sports engineering, 0xford, England,3 (3), 177-184, 2000.

12）飯本雄二, 田中了, 小林一敏：着地衝撃に関 する力学的研究, 日本体育学会第 34 回大会号, p.370, 1983.

13）菅原秀二，小林一敏：スパイクピン貫入によ る衝撃緩和の研究, 日本体育学会第 34 回大会 号, p.369, 1983.

14）山田憲政，小林一敏：走行中のスベリ緩衝に ついての力学的研究, 日本体育学会第 34 回大 会号, p.371, 1983.

15）小林一敏 他；スポーツ舗装材の各種走行状態 における緩衝性についてのコンピュータ・シ ミュレーションによる評価, 日本機械学会, ジョイント・シンポジウム講演論文集, 01-22, pp.9-13, 2001.

16）小林一敏 他 ; 身体に与える合成樹脂系舗装材 の力学的特性, 順天堂大学保健体育紀要, 第 18 号, pp.24-35, 1975.

17）金子靖仙；速く走るためのシューズ，精密工 学会誌, Vol.63, No.4, pp.460-465, 1997.

18）田中克昌 他；ランニング・シューズの機械的 特性とランナーによる官能評価との相関 一ト ラック弾性の影響一, スポーツ産業学研究, Vol.10, No.1, pp.35-43, 2000.

19）福岡正信；シューズはどう科学されるのかー シューズ機能の評価法一, 日本機械学会誌, Vol.95, No.888, pp.28-32, 1992.

20) Sock Heng WOO他 ; ランニング・シューズの 力学特性の計測と評価法, 日本機械学会論文 集 (C 編), 64 巻 623号, pp.85-92, 1998.

21）古川源蔵; スポーツサーフェスと安全性, 快適 性, 日本機械学会誌, Vol.95, No.888, pp.33-35, 1992.

22) Robert D. D’ Ambrosia, et al. ; Running Injuries, SLACK, TOKYO, pp.105-144, 1993.

23) Steven T. McCaw ; Qualitative Biomechanical Analysis to Understand Injury Development,
Biomechanics of Sport and Exercise 2nd Edition, HUMAN KINETICS, USA. pp.323-332. 2005.

24）菊川久夫 他 ; スポーツによる骨軟骨障害発生 に関する実験的研究, 東海大学スポーツ医科 学雑誌, 第 8 号, pp.73-77,1996.

25）菊川久夫 他; スポーツによる骨軟骨障害発生 に関する実験的研究 (第 2 報), 東海大学スポー ツ医科学雑誌，第 9 号, pp. 68-73, 1997.

26）（財）日本体育施設協会屋外体育施設部会; 「屋 外体育施設の建設指針 H17 年改訂版」, p.246, 2005.

27）須藤路久 他; 高速度カメラを用いた準剛体球 の衝突挙動解析, 可視化情報, vol.22 Suppl., No.1, pp.153-156, 2002.

28）上原謙他； $\mathrm{AE}$ センサを用いた弾塑性領域に おける反発係数の計測, トライボロジー会議 予稿集, 2001-11, pp.423-424, 2001.

29) Peter M.McGinnis ; Biomechanics of Sport and Exercise, HUMAN KINETICS, 2nd ed. pp.19-46. 2005.

30）福田厚治, 伊藤 章: 最高疾走速度と接地期の 身体重心の水平速度の減速・加速 : 接地によ る減速を減らすことで最高速度は高められる か: 体育学研究, 49, pp,29-39,2004.

31) Payne,A.H. : A comparison of the ground forces in race walking with those in normal walking and running. Biomechanics VI-A ; E.Asmussen and K.Jorgensen (ed.), Baltimore : University Park Press, pp.293-302, 1978.

32) Payne,A.H. : Foot to ground contact forces of elite runners. In : Biomechanics VIII-B ; H.Matsui and K.Kobayashi (ed.), Champaign, I 11. : Human Kinetics Publishers, pp.746-753, 1983.

33) Jess Jarver EDITED : SPRINTS \& RELAYS.5th, Tafnews Press, usa, pp.68-72, 2000.

34）小林一敏 他; 身体に与える合成樹脂系舗装材 の力学的特性, 順天堂大学保健体育紀要, 第 18 号, pp.24-35, 1975. 